\title{
Monitoring the fish fauna in the Wadden Sea with special reference to different fishing methods and effects of wind and light on catches*
}

\author{
Volkmar Hinz \\ Institut für Hydrobiologie und Fischereiwissenschaft, Universität Hamburg; \\ Ausrüstungskai 6, D-2000 Hamburg 50, Federal Republic of Germany
}

\begin{abstract}
The seasonal and local distribution of fish in the Wadden Sea depends on the various modes of life of each species. To obtain nearly all species of the fish fauna and the stages of development in different spatial regions of the Wadden Sea - shallow and deep channels, puddles and pools, sedimentation fields and tidal flats - it is essential to use different fishing methods synchronously. During a two-year monitoring project in 1986 and 1987 on fish and fisheries in a restricted area of the Wadden Sea of Schleswig-Holstein, five types of fishing gear were used synchronously: handnet, push-net, 2 -m beam trawl, commercial shrimp trawl, fyke net. In 822 samples of all gear 33 species were caught. No gear obtained the maximum number of species. Day and night samples show considerably different composition. Furthermore, force and direction of wind have an important effect on the distribution of fish in the coastal area. The advantages and disadvantages of the different gear for monitoring purposes are discussed from scientific and practical viewpoints.
\end{abstract}

\section{INTRODUCTION}

Fishery investigations in the Wadden Sea have been carried out since the end of the last century. Most of the earlier studies, the present monitoring activities of the International Demersal Young Fish Survey, and the By-catch Investigations of the German Shrimp Fishery are limited to the deeper tidal channels and inlets, or they deal with the biology of single species, particularly with commercially important species. During the last two decades, increasing attention has been paid to shallow tidal channels, tidal flats and, in general, near-shore areas. According to the various habitats in the shallow Wadden Sea area, fishing methods varied between 2-m beam trawls (e.g. Kuipers, 1973, 1975, 1977; Getzewitz, 1979; Lillelund \& Berghahn, 1981; van der Veer, 1986), 3-m and 6-m shrimptrawls (van Beek et al., 1989), commercial shrimptrawl (Tiews, 1983), enclosures (Ruth, 1981), fyke nets (Hinz, 1983), beach seines (Piepenburg, 1984), and push-nets (Berghahn, 1983). Simultaneous samplings with different fishing gear were applied by Berghahn (1986) for the first time. Furthermore, Berghahn (1983) estimated the density of juvenile fish in shallow puddles by direct observations.

The present paper describes experiences and results derived from simultaneous use

\footnotetext{
- Presented at the VI International Wadden Sea Symposium (Biologische Anstalt Helgoland, Wattenmeerstation Sylt, D-2282 List, FRG, 1-4 November 1988)
} 
of five fishing methods - push-net, handnet, 2-m beam trawl, by-catch, fyke net - in a two-year monitoring project in the Wadden Sea of Schleswig-Holstein. The different species, their abundance as well as their seasonal and spatial distribution were registered.

\section{MATERIALS AND METHODS}

The investigation was carried out in the southern part of the "Nationalpark Schleswig-Holsteinisches Wattenmeer" (Fig. 1). The area is limited by the coastline in the east and the outer sandbars in the west from the estuary of the Elbe river to the island Trischen.

The region is characterized by large tidal flats and several deep tidal channels and gullies. The mean tidal range is about $3.2 \mathrm{~m}$ and the mean tidal high water level about $1.55 \mathrm{~m}$ above sea level. The salinity ranged from $16 \%$ to $28 \%$.

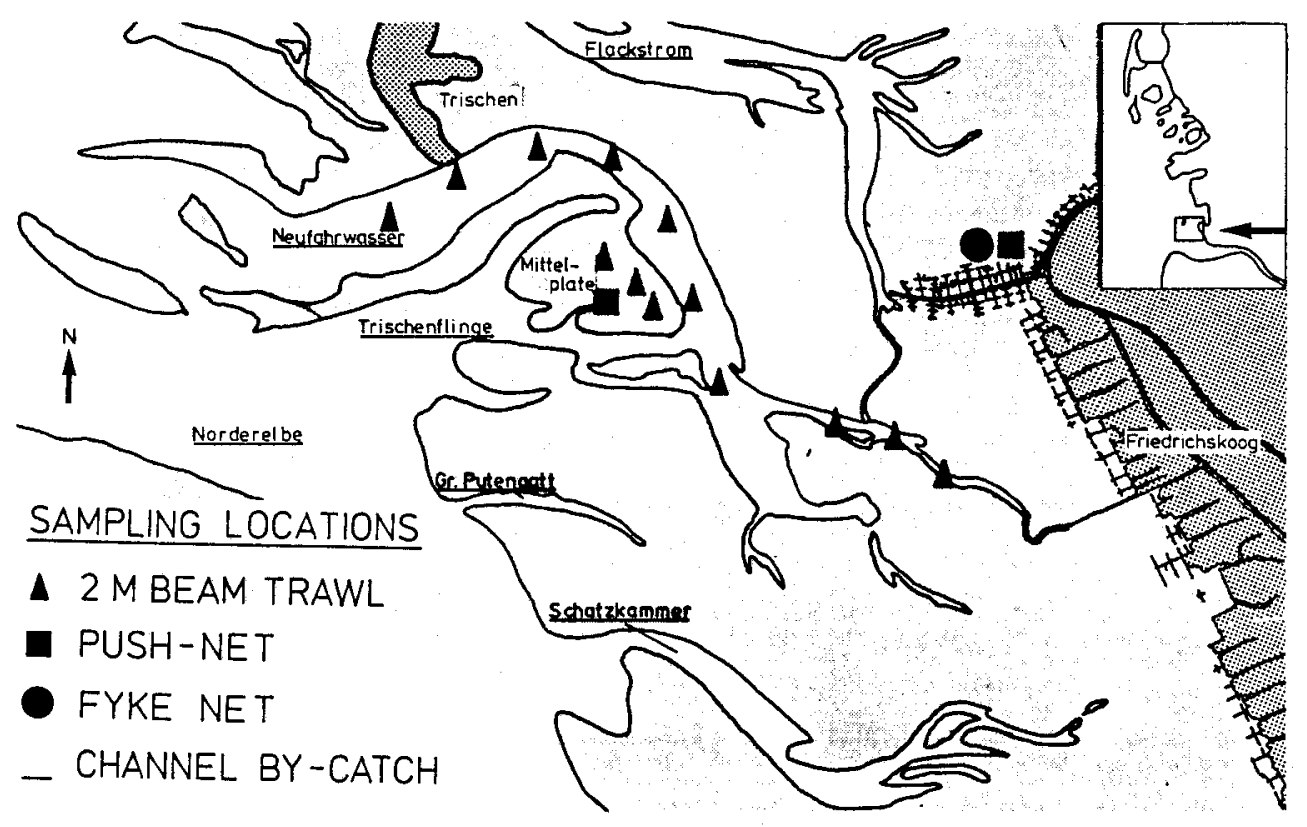

Fig. 1. Area of investigation, and sampling stations with different fishing methods used

\section{Tidal flats}

All the flats directly on the coastline of western Schleswig-Holstein are characterized by sedimentation fields. High water currents during flood and ebb tide create valleys in the narrow gates of pile-works. At low tide the density of juvenile fish in these tidal pools $\left(0-40 \mathrm{~cm}\right.$ water depth, $\left.300-1000 \mathrm{~m}^{2}\right)$ were estimated with a $1.5 \mathrm{~m}$ push-net according to Riley (1971), frame-altitude $30 \mathrm{~cm}$, mesh-size $1.4 \mathrm{~mm}$ (Fig. 2). Tidal puddles (0-5 cm water depth) on the flat were investigated by direct observation or a handnet (Fig. 2).

Fish migrating tidally to the near shore zone at Friedrichskoog were sampled during high tide with fyke nets (Fig. 2). The use of beam trawls was not possible because of the 


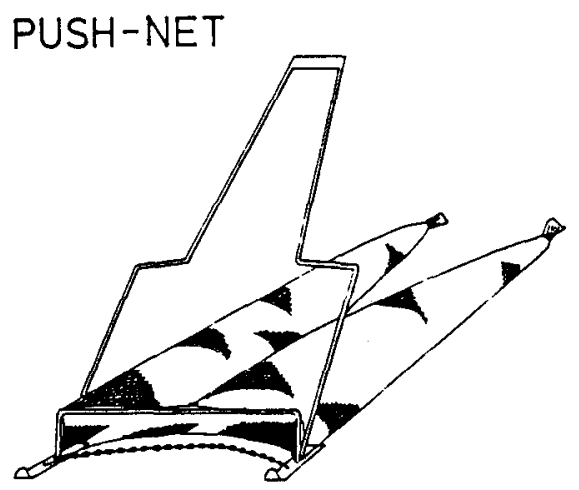

HANDNET

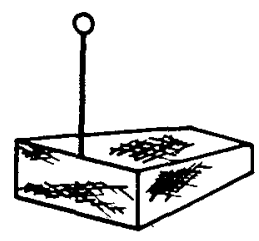

\section{BEAM TRAWL}

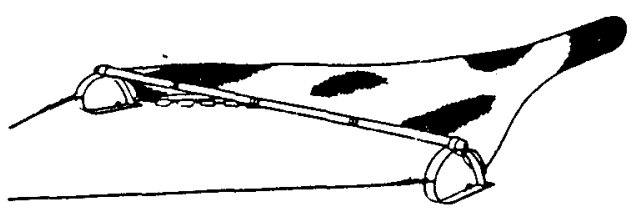

\section{FYKE NET}

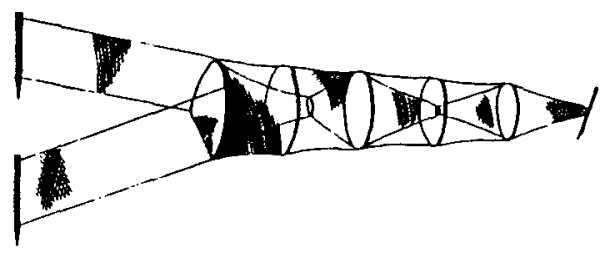

Fig. 2. The fishing gear

shallow water. The fyke nets were located at the end of the pile-works and at the gates, the net opening was always directed against ebb flow (Hinz, 1983). The mesh size was $16 \mathrm{~mm}$ in the wings, $12 \mathrm{~mm}$ in the first basket and $10 \mathrm{~mm}$ in the second basket. The fyke nets were controlled after each flood tide.

The sandy flat Mittelplate, situated $7 \mathrm{~km}$ offshore, is isolated from other flats by tidal channels (Fig. 1). Hauls were made with a 2-m beam trawl (Fig. 2), net opening $1.90 \mathrm{~m}$, 
with one tickler chain and a mesh size of $5 \mathrm{~mm}$ (Kuipers, 1975). The device was towed by a $5.20-\mathrm{m}$ flat-bottomed boat (25 HP, DECCA-navigator, echo-sounder). The length of the fishing line ranged from $15 \mathrm{~m}$ to $20 \mathrm{~m}$ depending on water depth. The distance of each haul was determined by a meter-wheel fixed at the frame of the gear. Fishing on the tidal flats was carried out during daytime and continued from 2 hours before high tide to 2 hours after.

\section{Channels}

The main channel in the investigation area is the Neufahrwasser, running from the harbour of Friedrichskoog northwest alongside of Mittelplate, then turning west to the North Sea (Fig. 1). Maximum depth is about $12 \mathrm{~m}$ to $14 \mathrm{~m}$. The tidal channel was físhed during low water with the $2-\mathrm{m}$ beam trawl on the same days as the Mittelplate was investigated with this gear during high water. The water depths at the sampling stations in the tidal channel varied between $0.8 \mathrm{~m}$ and $7.0 \mathrm{~m}$, in general about $2 \mathrm{~m}$.

Furthermore, the composition of the fish fauna in the Neufahrwasser and other deep channels (underlined in Fig. 1) was examined in sub-samples from the by-catch of commercial shrimp trawlers (Tiews, 1983). During fishing the investigator was aboard and noted position, tidal period, depth, total catch etc. for each haul. In general, haul duration was one hour. In winter and spring, it took up to two hours. The beam of the trawls employed ranged from $8 \mathrm{~m}$ to $10 \mathrm{~m}$. Mesh-size in the cod end was $10 \mathrm{~mm}$.

The abundance of fish in a shallow channel at the Mittelplate, depth up to $0.90 \mathrm{~m}$, was determined with the push-net.

An overview of the fishing methods and their application is given in Table 1. The investigations were carried out monthly on successive days from April to December in 1986 and 1987 . Altogether 822 samples were made, exclusively handnet catches. The number of hauls per device are given in Table 2 .

Table 1. Fishing methods in different habitats of the Wadden Sea at Friedrichskoog

\begin{tabular}{|c|c|c|c|c|c|}
\hline Objects & Fishing gear & $\begin{array}{l}\text { Mesh size } \\
\quad(\mathrm{mm})\end{array}$ & $\begin{array}{l}\text { Width } \\
\text { (m) }\end{array}$ & Location & $\begin{array}{l}\text { Waterdepth } \\
\text { (m) }\end{array}$ \\
\hline \multirow[t]{2}{*}{$\begin{array}{l}\text { Postlarvae, } \\
\text { young fish }\end{array}$} & Push-net & 1.4 & 1.5 & $\begin{array}{l}\text { Tidal pools } \\
\text { Shallow channels }\end{array}$ & $0-0.9$ \\
\hline & Handnet & 1.4 & 0.2 & $\begin{array}{l}\text { Tidal puddles } \\
\text { Tidal pools }\end{array}$ & $0-0.2$ \\
\hline \multirow{3}{*}{$\begin{array}{l}\text { Young fish, } \\
\text { adults, } \\
\text { larger fish }\end{array}$} & 2-m beam trawl & 5.0 & 2.0 & $\begin{array}{l}\text { Channels } \\
\text { Tidal flats }\end{array}$ & $\begin{array}{l}1-7.0 \\
1-2.5\end{array}$ \\
\hline & $\begin{array}{l}\text { Commercial shrimp } \\
\text { beam trawl }\end{array}$ & 10.0 & $8-10$ & $\begin{array}{l}\text { Channels } \\
\text { Outer parts }\end{array}$ & $2-14.0$ \\
\hline & Fyke net & 10.0 & 3.0 & $\begin{array}{l}\text { Sedimentation } \\
\text { fields }\end{array}$ & $0-2.0$ \\
\hline
\end{tabular}


Table 2. Number of hauls using different fishing methods in 1986 and 1987

\begin{tabular}{lrrr|}
\hline Fishing gear & 1986 & 1987 & Total \\
\hline Push-net & 128 & 107 & 235 \\
2-m beam trawl & 157 & 145 & 302 \\
Commercial shrimp beam trawl & 45 & 43 & 88 \\
Fyke net & 119 & 78 & 197 \\
Total & 449 & 373 & 822 \\
\hline
\end{tabular}

\section{RESULTS}

In the research area at Friedrichskoog, 33 fish species were recorded (Table 3). Species were classified into different ecological groups. The members of the first main group either prefer or depend on the Wadden Sea for spawning, nursery or feeding grounds. In the second group, temporary or accidental visitors are listed.

The whole variety of species was never obtainable with just one type of gear. Commercial beam trawls caught nearly all species except the thicklipped mullet (Mugil chelo). Mullets and other large fish, such as sea trout (Salmo trutta trutta) and garfish (Belone belone), were exclusively caught by the bigger or passive devices like commercial trawl and fyke net respectively.

24 species were recorded with the 2-m beam trawl, 23 in the tidal channels and 17 on the tidal flats. Push-net catches obtained 18 , and the fyke nets only 16 species. However, these results from fyke net samples may be biased since a strong ice-drift in 1986 and 1987 destroyed many of the pile-works that are normally supposed to lead the fish to the gear.

\section{Seasonal distribution}

On their way to the freshwater spawning grounds, stickleback (Gasterosteus aculeatus) was highly abundant in spring. Hundreds of sticklebacks were caught in a single fyke net, while in the other devices only few individuals were retained. Typical summer guests were sole (Solea solea), mullet and garfish. Dab (Limanda limanda) became more and more abundant in autumn. Throughout the year, herring (Clupea harengus), smelt (Osmerus eperlanus), plaice (Pleuronectes platessa), flounder (Platichthys flesus), sand goby (Pomatoschistus minutus), eelpout (Zoarces viviparus) and little pipefish (Syngnathus rostellatus) were abundant.

The strict temporally limited and successive appearance of postlarval stages in the tidal pools is demonstrated in Table $4 \mathrm{a}$ and $4 \mathrm{~b}$. In April, 0 -group herring and newly settled plaice were the only species. One month later, the number of herring decreased, plaice reached maximum density and the immigration of the youngest flounders began. When juvenile flounders started their tidal migration to the channels, early juvenile stages of gobies immigrated and remained in the tidal pools during ebb tide. All 0-group stages mentioned above were exclusively caught with small-mesh push-nets. 
Table 3. Fish species caught in the Wadden Sea area at Friedrichskoog using different methods. $\mathrm{C}=$ Channel; $\mathrm{P}=$ Tidal Pool; $\mathrm{F}=$ Tidal flat

\begin{tabular}{|c|c|c|c|c|c|}
\hline Species & & $\begin{array}{l}\text { Push-net } \\
\text { C/P }\end{array}$ & $\begin{array}{c}\text { Beamtrawl } \\
2 \mathrm{~m} \\
\mathrm{C} / \mathrm{F}\end{array}$ & $\begin{array}{l}\text { Beamtrawl } \\
\text { Commercial }\end{array}$ & Fyke net \\
\hline Agonus cataphractus & (Hook-nose) & & $\mathrm{x} / \mathrm{x}$ & $\mathrm{x}$ & $\mathrm{x}$ \\
\hline Liparis liparis & (Sea snail) & & $\mathrm{x} /$ & $\mathbf{x}$ & \\
\hline Myoxocephalus scorpius & (Bull rout) & $\mathrm{x} /$ & $\mathrm{x} / \mathrm{x}$ & $\mathbf{x}$ & \\
\hline Pholis gunnellus & (Butterfish) & $/ \mathrm{x}$ & $\mathrm{x} /$ & $\mathrm{x}$ & \\
\hline Pomatoschistus microps & (Common goby) & $\mathrm{x} / \mathrm{x}$ & $x / x$ & $\mathrm{x}$ & \\
\hline Zoarces viviparus & (Eelpout) & $x / x$ & $x / x$ & $\mathbf{x}$ & $\mathrm{x}$ \\
\hline Pomatoschistus minutus & (Sand goby) & $\mathrm{x} / \mathrm{x}$ & $\mathrm{x} / \mathrm{x}$ & $\mathrm{x}$ & $\mathbf{x}$ \\
\hline Platichthys flesus & (Flounder) & $\mathrm{x} / \mathrm{x}$ & $\mathrm{x} / \mathrm{x}$ & $\mathbf{x}$ & $\mathrm{x}$ \\
\hline Ciliata mustela & $\begin{array}{l}\text { (Five-bearded } \\
\text { rockling) }\end{array}$ & $\mathrm{x} /$ & $\mathrm{x} /$ & $\mathrm{x}$ & $\mathrm{x}$ \\
\hline Salmo trutta trutta & (Sea trout) & & & $\mathbf{x}$ & $\mathrm{x}$ \\
\hline Belone belone & (Garfish) & & & $\mathrm{x}$ & $\mathrm{x}$ \\
\hline Syngnathus rostellatus & (Little pipe-fish) & $\mathrm{x} /$ & $\mathrm{x} / \mathrm{x}$ & $\mathrm{x}$ & \\
\hline Cyclopterus lumpus & (Lumpsucker) & & & $\mathrm{x}$ & $x$ \\
\hline Clupea harengus & (Herring) & $\mathrm{x} / \mathrm{x}$ & $\mathrm{x} / \mathrm{x}$ & $\mathbf{x}$ & $\mathbf{x}$ \\
\hline Pleuronectes platessa & (Plaice) & $\mathrm{x} / \mathrm{x}$ & $x / x$ & $\mathbf{x}$ & $x$ \\
\hline Sprattus sprattus & (Sprat) & $\mathrm{x} / \mathrm{x}$ & $\mathrm{x} / \mathrm{x}$ & $\mathbf{x}$ & $\mathrm{x}$ \\
\hline Solea solea & (Sole) & $\mathrm{x} /$ & $x / x$ & $\mathbf{x}$ & $\mathrm{x}$ \\
\hline Mugil chelo & $\begin{array}{l}\text { (Thicklipped } \\
\text { mullet) }\end{array}$ & & & & $\mathrm{x}$ \\
\hline Gasterosteus aculeatus & (Stickleback) & $\mathrm{x} / \mathrm{x}$ & $\mathrm{x} / \mathrm{x}$ & $\mathrm{x}$ & $x$ \\
\hline Osmerus eperianus & (Smelt) & $x / x$ & $\mathrm{x} / \mathrm{x}$ & $\mathbf{x}$ & $\mathbf{x}$ \\
\hline Anguilla anguilla & $(\mathrm{Eel})$ & $\mathrm{x} / \mathrm{x}$ & $x /$ & $\mathbf{x}$ & $\mathbf{x}$ \\
\hline Gadus morhua & (Cod) & & $\mathrm{x} /$ & $\mathrm{x}$ & \\
\hline Merlangius merlangus & (Whiting) & & $\mathrm{x} /$ & $\mathbf{x}$ & \\
\hline Psetta maxima & (Turbot) & & $\mathrm{x} / \mathrm{x}$ & $\mathbf{x}$ & \\
\hline Scophthalmus rhombus & (Brill) & & & $\mathrm{x}$ & \\
\hline Zeugopterus punctatus & (Topknot) & & & $\mathbf{x}$ & \\
\hline Trisopterus luscus & (Bib) & & & $\mathrm{x}$ & \\
\hline Ammodytes lancea & (Sandeel) & $\mathrm{x} /$ & $\mathrm{x} /$ & $\mathbf{x}$ & \\
\hline Buglossidium luteum & (Solenette) & & $/ \mathrm{x}$ & $\mathbf{x}$ & \\
\hline Callionymus lyra & (Dragonet) & $\mathrm{x} /$ & $x / x$ & $\mathrm{x}$ & \\
\hline Limanda limanda & (Dab) & $\mathrm{x} /$ & $\mathrm{x} / \mathrm{x}$ & $\mathrm{x}$ & \\
\hline Trachurus trachurus & (Scad) & & & $\mathrm{x}$ & \\
\hline Lampetra fluviatilis & (Lampern) & & & $\mathrm{x}$ & \\
\hline Number of species & 33 & $\begin{array}{c}18 \\
(17 / 11)\end{array}$ & $\begin{array}{c}24 \\
(23 / 17)\end{array}$ & 32 & 16 \\
\hline
\end{tabular}


Table 4a. Maximum density $\left(\mathrm{n} / 1000 \mathrm{~m}^{2}\right)$ of juvenile fishes in the tidal pools at Friedrichskoog in 1986

\begin{tabular}{|lrrrrr|}
\hline Month & Herring & Plaice & Flounder & Common goby & Sand goby \\
\hline Apr. & 5970 & 1430 & & & \\
May & 560 & 4890 & 1200 & & \\
June & & 300 & 7500 & & \\
July & & & 430 & 210 & 50 \\
Aug. & & & 52 & 3020 & 3510 \\
Sept. & & 67 & 9970 & 3560 \\
Oct. & & & 802 & 6970 \\
Nov. & & & & 240 & 1440 \\
\hline
\end{tabular}

Table $4 \mathrm{~b}$. Maximum density $\left(\mathrm{n} / 1000 \mathrm{~m}^{2}\right)$ of juvenile fishes in the tidal pools at Friedrichskoog in 1987

\begin{tabular}{|c|c|c|c|c|c|}
\hline Month & Herring & Plaice & Flounder & Common goby & Sand goby \\
\hline Apr. & 44 & 22 & & & \\
\hline May & & 2080 & 7410 & & \\
\hline June & & & 3870 & & \\
\hline July & & & 490 & 490 & \\
\hline Aug. & & & & 4210 & \\
\hline Sept. & & & & 10580 & 20 \\
\hline Oct. & & & & 2400 & 130 \\
\hline Nov. & & & & 510 & \\
\hline
\end{tabular}

\section{Local distribution}

Tidal migrations are typical for later stages of common goby (Pomatoschistus microps), sand goby, eelpout, flounder, plaice, sole, eel (Anguilla anguilla), and pelagic fish such as herring, smelt and stickleback. They leave the channels with the rising tide to feed on the tidal flats.

In contrast, hook-nose (Agonus cataphractus), sea snail (Liparis liparis), bull rout (Myoxocephalus scorpius), butterfish (Pholis gunnellus) and five-bearded rockling (Ciliata mustela) avoided tidal migration, although they were occasionally caught in low numbers on the tidal flats.

During low tide in the tidal channels, plaice prefer the upper sublitoral, as demonstrated in samples with the 2-m beam trawl (Fig. 3). Highest densities were always in water levels less than 2 meters. In general, this channel region is not swept by commercial beam trawls. A single reversed distribution in August is probably caused by strong winds $(7-8 \mathrm{bft})$. It is likely that turbulences caused by wave movements occasion the plaice to leave the shallow region.

\section{Wind situation}

In areas close to the coast, force and direction of wind influence the distribution of fish. Analysis of 641 own fyke net samples and recordings of a local fisherman in 1981 and 1982 indicated that the yield of catches is influenced by the wind (Figs 4 and 5). Total 


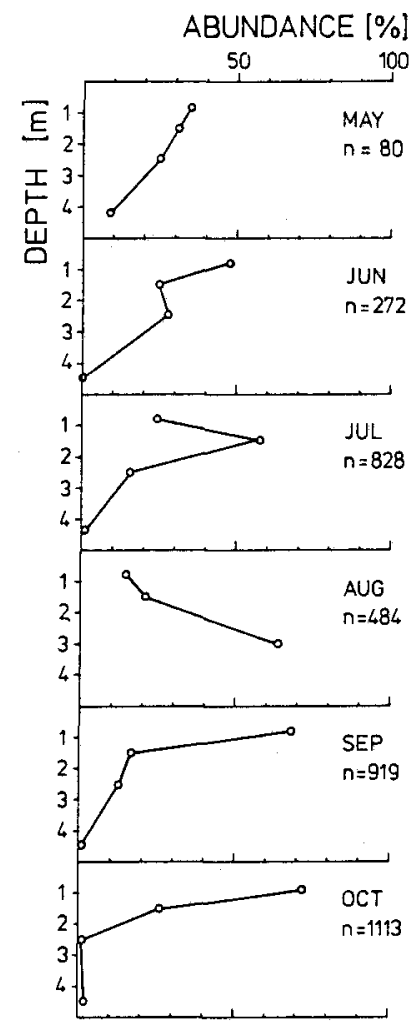

Fig. 3. Abundances of juvenile plaice in relation to waterdepth in the upper sublittoral of a channel during low water $(\mathrm{n}=$ total number of plaice caught)

catch and, respectively, numbers of flounders increased when the wind turned from offshore direction to onshore direction. Offshore winds on the other hand led to decreasing yields. The catches became even smaller when offshore winds continued for several days.

\section{Light condition}

The distribution pattern of several species is influenced by light condition. Analysis of fyke net samples on tidal flats at the shore-line, far off the main channel, showed considerably different results for day and night catches (Table 5). For the comparison of catches, only successive tide periods with identical wind situations were considered. The numbers of plaice and flounder in the catch were significantly higher during daytime, while sole and eel were much more abundant during the night.

\section{DISCUSSION}

Altogether 33 fish species were recorded in the area at Friedrichskoog in this study. In the North Frisian area of the Schleswig-Holstein Wadden Sea, Getzewitz (1980) caught 26 species, Lillelund \& Berghahn (1981) 33 species, Hinz (1983) 25 species and Piepen- 
burg (1984) 28 species. The duration of these investigations ranged from 7 months to two years at a maximum.

Meyer-Waarden \& Tiews (1965) examined 3756 sub-samples from the by-catch of German shrimpers from 1954 to 1960 , registering thereby 46 fish species. With reference to several publications, Witte \& Zijlstra (1979) listed 70 species in total for the German part of the Wadden Sea. It is obvious that the differences in the numbers of species in these projects are mainly caused by factors like time, space, fishing gear and number of samples. These main factors have to be standardized for monitoring purposes. Furthermore, monitoring has to be performed over many years in order to detect long-term changes in the fish fauna.

Seasonal and local distribution of fish in different Wadden Sea habitats depends on the varied mode of life of each species. The distribution pattern of fish species in the Friedrichskoog area is in general similar to that of fish species in other regions of the Wadden Sea (Fonds, 1979; Berghahn, 1987). In contrast to Berghahn (1987), no postlarval stages of sole occurred in the tidal pools; the reason is still unknown.

Concerning the diurnal differences in the fyke net catches, similar results with other gear and in other regions of the North Sea were obtained by de Groot (1971) and de Veen (1978) for plaice, by Kruuk (1963) and de Groot (1971) for sole and Tesch (1973) for eel.

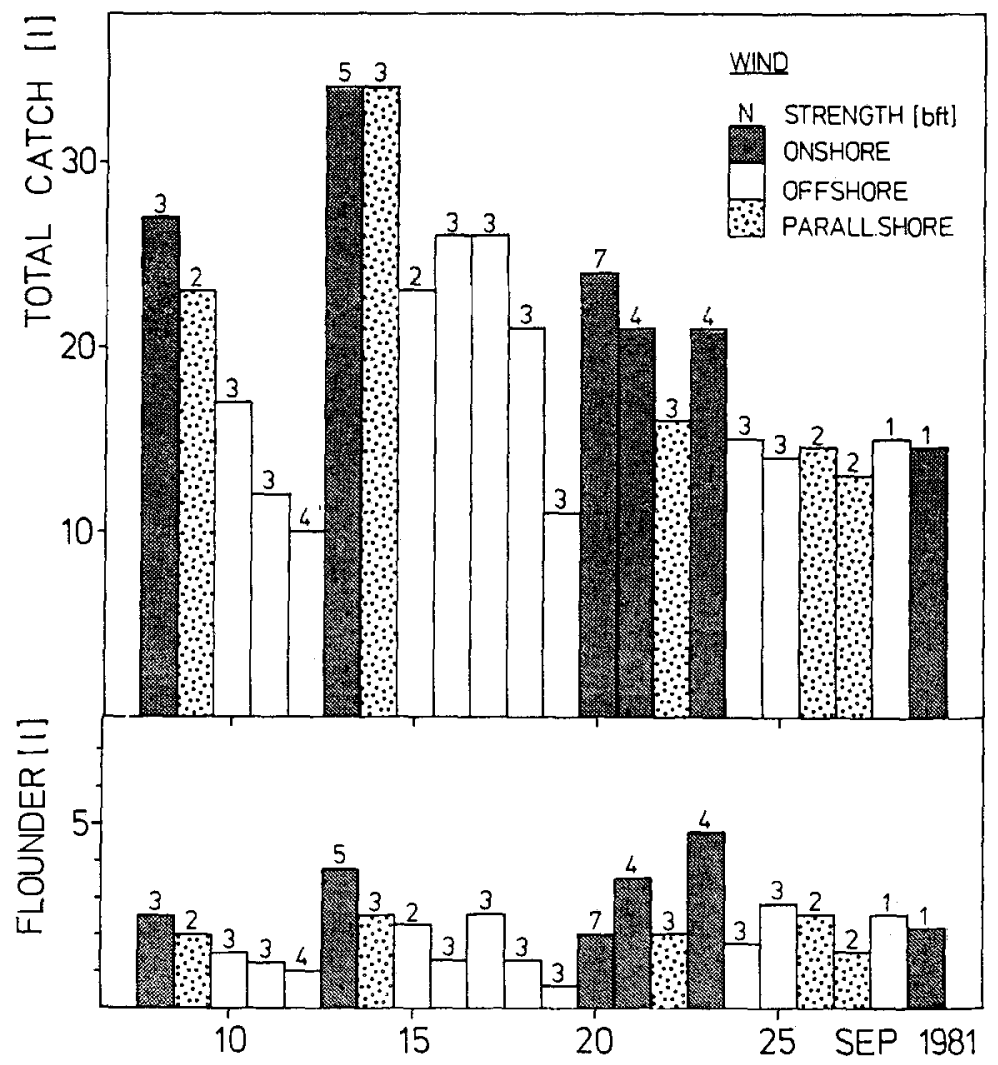

Fig. 4. Yields of fyke net catches dependent on the wind situation in $1981(1=$ volume in litre $)$ 

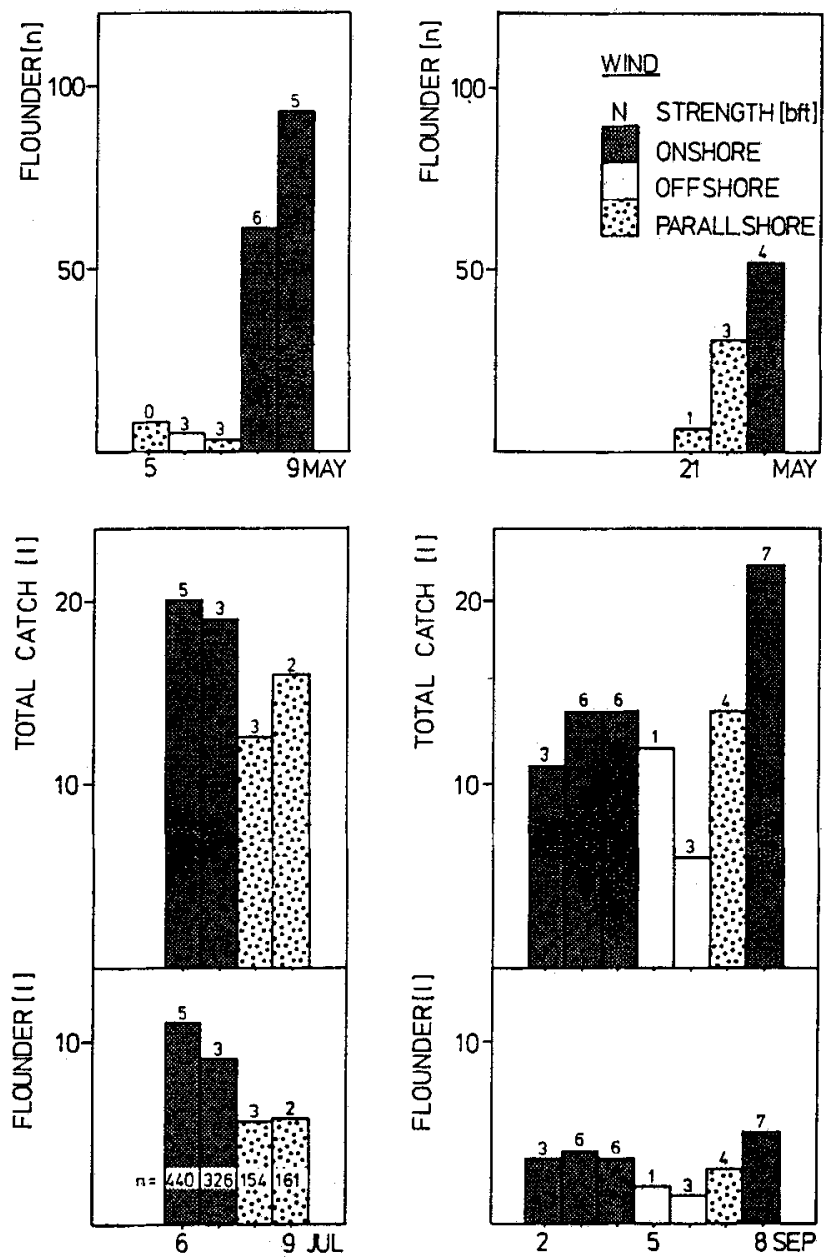

Fig. 5. Yields of fyke net catches dependent on the wind situation in $1982(\mathrm{l}=$ volume in litre, $\mathrm{n}=$ total number)

In many cases, it is likely that diurnal differences in the catches are not caused by different distribution patterns but by light-dependent variations in fish activity and gear efficiency.

However, it has also been demonstrated by Hinz (1983) and Berghahn (1986) that the different numbers of fishes (e.g. plaice) in the samples taken on tidal flats during day and night can indicate a different distribution pattern. During the night, the numbers of plaice near the tidal channel were considerably higher than during daytime, when plaice spread all over the tidal flats up to the shore-line.

Furthermore, wind direction and wind force effect the yields of catches as demonstrated above. On tidal flats, Lillelund \& Berghahn (1981) obtained yields of plaice up to four times higher during onshore winds than during offshore winds. With regard to shrimps, the influence of wind became much more evident. Harden Jones \& Scholes 
Table 5. Number of fish in fyke nets on days with identical wind situation for night and day in 1982.

- Night; O Day

\begin{tabular}{|c|c|c|c|c|c|c|c|c|c|c|c|c|}
\hline \multirow[t]{2}{*}{ Date } & \multicolumn{2}{|c|}{ Flounder } & \multicolumn{2}{|c|}{ Plaice } & \multicolumn{2}{|c|}{ Sole } & \multicolumn{2}{|c|}{ Eel } & \multicolumn{2}{|c|}{ Herring } & \multicolumn{2}{|c|}{ Smelt } \\
\hline & - & 0 & - & 0 & - & 0 & - & 0 & - & 0 & - & 0 \\
\hline May 8 & 43 & 128 & & & & & & & & & & \\
\hline May 9 & 73 & 167 & & & & & & & & & 20 & 42 \\
\hline May 23 & 25 & 98 & 10 & 61 & & & & & & & 14 & 13 \\
\hline June 4 & 1 & 5 & 3 & 12 & & & & & & & & \\
\hline June 17 & 46 & 36 & 51 & 52 & 7 & 3 & 7 & 3 & 4 & 15 & 21 & 21 \\
\hline June 19 & 3 & 6 & 0 & 11 & 3 & 0 & 2 & 2 & 31 & 3 & 11 & 0 \\
\hline June 22 & 215 & 294 & 15 & 80 & 38 & 0 & & & & & 1 & 4 \\
\hline July 7 & 205 & 393 & 134 & 322 & 37 & 1 & 1 & 2 & 11 & 2 & 5 & 0 \\
\hline July 19 & 2 & 8 & 1 & 8 & 6 & 0 & 2 & 0 & 70 & 53 & 51 & 5 \\
\hline Aug. 4 & 4 & 40 & 0 & 6 & & & 3 & 2 & 13 & 0 & & \\
\hline Aug. 17 & 6 & 30 & 0 & 10 & 4 & 0 & 15 & 4 & 14 & 114 & 3 & 2 \\
\hline Aug. 18 & 3 & 160 & 0 & 47 & & & 27 & 22 & 38 & 19 & 12 & 8 \\
\hline Aug. 19 & 2 & 28 & 0 & 13 & & & & & & & & \\
\hline Oct. 3 & 97 & 470 & 66 & 278 & & & & & & & & \\
\hline Oct. 14 & 0 & 31 & 0 & 10 & & & 30 & 3 & 1 & 52 & 2 & 19 \\
\hline Oct. 17 & 7 & 56 & 1 & 1 & & & 9 & 4 & 30 & 34 & 5 & 0 \\
\hline Relation & & $<0$ & & $<0$ & $\bullet$ & 0 & $\bullet$ & 0 & & 0 & $\bullet$ & 60 \\
\hline $\begin{array}{l}\text { Signific. } \\
(p<0.05 \%)\end{array}$ & & & & & & & & & & & & \\
\hline
\end{tabular}

(1980) and Scholes (1982) analysed catches of Lowestoft trawlers in the North Sea and found several examples in which a marked and statistically significant fall in the catch rate of plaice was correlated with northeasterly winds. Otherwise, they found examples too which show no significant effect of wind situations on catches. In accordance with Scholes (1982), it is desirable to collect and analyse much more data for statistical proof that there is a causal and not just a casual relationship between wind condition and catch rate.

Finally, the choice and the use of different fishing methods are dependent on the goal of the investigation. The commercial beam trawler was most effective in catching the species present. Quantitative investigations are possible. It is suitable for investigations in the deeper channels and the outer regions of the Wadden Sea.

Fishing with the $2-\mathrm{m}$ beam trawl is suitable on flats as well as in channels and allows quantitative sampling on 0-group flatfish and other demersal species. Kuipers (1975, 1977 ) determined the efficiency of the trawl for plaice, which are more or less randomly distributed on the flats during high tide. On the other hand, pelagic and large fish are caught only accidentally. The push-net is an important fishing gear for small and young individuals in tidal pools and shallow channels. The beach seine (Ruth \& Berghahn, 1989) is an alternative device for shallow habitats.

Finally the fyke net, which is not very common in fishery research, is suitable gear for fishing in shallow waters (Fonds, 1979). Large and fast individuals as well as pelagic specimen were better obtained with this device than with the $2-\mathrm{m}$ beam trawl. One 
disadvantage of the fyke nets is the fact that only one sample per tide and gear can be taken.

To obtain information on the total fish community, i.e. all species, their abundance, their distribution and their stages of development, it is essential that different fishing methods are used synchronously throughout the year.

Considering the different objectives of monitoring programs (Ruth \& Berghahn, 1989), e.g. stock assessment of a single species, the use of only one or two fishing gear may be sufficient. For all kinds of monitoring studies, care must be taken that the fishing method is not altered during the project.

Furthermore, light condition, space, season and the individual pattern of behaviour of each species determine the choice of the gear. The methods described above are common and easy to handle. They cover all the different habitats, in particular the shallow regions, which are most important for many species.

\section{LITERATURE CITED}

Beek, F. A. van, Rijnsdorp, A.D. \& Clerk, R. de, 1989. Monitoring juvenile stocks of flatfish in the Wadden Sea and the coastal areas of south eastern North Sea. - Helgoländer Meeresunters. 43, $461-477$.

Berghahn, R., 1983. Untersuchungen an Plattfischen und Nordseegarnelen (Crangon crangon) im Eulitoral des Wattenmeeres nach dem Übergang zum Bodenleben. - Helgoländer Meeresunters. $36,163-181$.

Berghahn, R., 1986. Determining abundance, distribution, and mortality of 0-group plaice (Pleuronectes platessa L.) in the Wadden Sea. - J. appl. Ichth. 2, 11-22.

Berghahn, R., 1987. The Wadden Sea as a nursery for fish and crustacean species. In: Proceedings of the 5th International Wadden Sea Symposium. Ed. by S.'Tougaard \& S. Asbirk. The National Forest and Nature Agency and the Museum of Fisheries and Shipping, Esbjerg, 69-85.

Fonds, M., 1979. The seasonal distribution of some fish species in the western Dutch Wadden Sea. In: Fishes and fisheries of the Wadden Sea. Ed. by N. Dankers, W. J. Wolff \& J.J. Zijlstra. Balkema, Rotterdam, 42-77. (Rep. Wadden Sea Working Group. 5.)

Getzewitz, P., 1979. Die Bedeutung der Nordstrander Bucht als Aufwuchsgebiet für Jungfische. Dipl.-Arb. Univ. Kiel, 56 pp.

Groot, S. J. de, 1971. On the interrelationship between morphology of the alimentary tract, food and feeding behaviour in the flatfishes (Pisces: Pleuronectiformes). - Neth. J. Sea Res. 5, 121-196.

Harden Jones, F. R. \& Scholes, P., 1980. Wind and the catch of a Lowestoft trawler. - J. Cons, int. Explor. Mer 39, 53-69.

Hinz, V., 1983. Fischereibiologische Untersuchungen in ausgesuchten Lahnungsfeldern des Nordfriesischen Wattenmeeres. Dipl.-Arb., Univ. Hamburg, 115 pp.

Kruuk, H., 1963. Diurnal periodicity in the activity of the Common Sole, Solea vulgaris, Quensel. Neth. J. Sea Res. 2, 1-28.

Kuipers, B, 1973. On the tidal migration of young plaice (Pleuronectes platessa) in the Wadden Sea. - Neth. J. Sea Res. 6, 376-388.

Kuipers, B., 1975. On the efficiency of a two-meter beam trawl for juvenile plaice (Pleuronectes platessa). - Neth. J. Sea Res. 9, 69-85.

Kuipers, B., 1977. On the ecology of juvenile plaice on a tidal flat in the Wadden Sea. - Neth. J. Sea Res. 11, 56-91.

Lillelund, K. \& Berghahn, R., 1981. Gutachten zur Fischereibiologie der Nordstrander Bucht Kurzfassung. - SchrReihe Landesreg. Schlesw.-Holst. 12, 251-312.

Meyer-Waarden, P.F. \& Tiews, K., 1965. Der Beifang in den Fängen der deutschen Garnelenfischerei 1954-1960. - Ber. dt. wiss. Kommn Meeresforsch. 18, 13-78.

Piepenburg, D., 1984. Zum Auftreten von Fischen und Fischnährtieren in ausgewählten Prielen des Nordfriesischen Wattenmeeres. Dipl.-Arb., Univ. Kiel, 184 pp. 
Riley, J.D., 1971. The Riley push-net. In: Methods for the study of marine benthos. Ed. by N. A. Holme \& A. D. McIntyre. Oxford, Blackwell, 286-290.

Ruth, M., 1981. Fischereibiologische Untersuchungen im oberen Eulitoral des nordfriesischen Wattenmeeres unter besonderer Berücksichtigung der Meeräsche Mugil chelo Cuv. Dipl.-Arb., Univ. Kiel, $74 \mathrm{pp}$.

Ruth, M. \& Berghahn, R., 1989. Biological monitoring of fish and crustaceans in the Wadden Sea potential and problems. - Helgoländer Meeresunters. 43, 479-487.

Scholes, P., 1982. The effect of wind direction on trawl catches; an analysis of haul-by-haul data. J. Cons. int. Explor. Mer 40, 81-93.

Tesch, F. W., 1973. Der Aal. Parey, Hamburg, 306 pp.

Tiews, K., 1983. Über die Veränderungen im Auftreten von Fischen und Krebsen im Beifang der deutschen Garnelenfischerei während der Jahre 1954-1981. - Arch. FischWiss. 34, 1-156.

Veen, J.F. de, 1978. On selective tidal transport in the migration of North Sea plaice (Pleuronectes platessa) and other flatfish species. - Neth. J. Sea Res. 12, 115-147.

Veer, H. W. van der, 1986. Immigration, settlement, and density-dependent mortality of a larval and early postlarval 0-group plaice (Pleuronectes platessa) population in the western Wadden Sea. Mar. Ecol. Prog. Ser. 29, 223-236.

Witte, J. Y. \& Zijlstra, J.J., 1979. The species of fish occurring in the Wadden Sea. In: Fishes and fisheries in the Wadden Sea. Ed. by N. Dankers, W. J. Wolff \& J. J. Zijlstra. Balkema, Rotterdam, 10-19. (Rep. Wadden Sea Working Group. 5.) 